\title{
Leadership Styles Followed in Banking Industry of Bangladesh: A Case Study on Some Selected Banks and Financial Institutions
}

\author{
Ikhtiar Mohammad ${ }^{1}$, Shah Ridwan Chowdhury ${ }^{2}$, Nehad Laila Sanju ${ }^{3}$ \\ ${ }^{1}$ Research and Evaluation Division, Dhaka, Bangladesh \\ ${ }^{2}$ Department of Management, University of Dhaka, Dhaka, Bangladesh \\ ${ }^{3}$ Department of Management Information Systems, University of Dhaka, Dhaka, Bangladesh
}

Email address:

ikhti@hotmail.com (I. Mohammad), du.ridwan@gmail.com (S. R. Chowdhury), nehadlailasanju@du.ac.bd (N. L. Sanju)

\section{To cite this article:}

Ikhtiar Mohammad, Shah Ridwan Chowdhury, Nehad Laila Sanju. Leadership Styles Followed in Banking Industry of Bangladesh: A Case Study on Some Selected Banks and Financial Institutions. American Journal of Theoretical and Applied Business.

Vol. 3, No. 3, 2017, pp. 36-42. doi: 10.11648/j.ajtab.20170303.11

Received: April 26, 2017; Accepted: June 6, 2017; Published: July 21, 2017

\begin{abstract}
This paper reviews literature as well as explores analytical findings on leadership styles from the practical perspective. For this purpose, the banking industry of Bangladesh is taken as a sample industry. The sample units are taken from ten private and public commercial banks and non-bank financial institutions. The objective of this study is to explore the leadership practices in the banking industry of Bangladesh. Primary data has been collected from the top, mid and operational level officials of different banking institutions through face-to-face individual interviews using questionnaire. Analysis has been done from both leaders' and subordinates' perspectives. Major finding is that the most practiced leadership style according to both leaders and subordinates is bureaucratic style and the least used leadership style is laissez-faire style.
\end{abstract}

Keywords: Leadership Style, Banking Industry, Financial Institution, Bangladesh

\section{Introduction}

Leadership is one of the most salient aspects of the organizational context. Many people today are seeking to understand and many people are writing about the concept and practices of leadership. There are a great many reasons for the popularity of the topic, including that organizations are faced with changes like never before. The concept of leadership is relevant to any aspect of ensuring effectiveness in organizations and in managing change. It is really impressive that the different ways the subject is seen. Some say it's a process, some say it is ability, others say it is a relationship. However, impact of leadership on organization has been a center of concern as leadership influences organizations' performance and effective leadership is considered as a key factor in attracting, maintaining, and motivating employees in organizations undergoing change and transformation [16], [17].

From Mahatma Gandhi to Jack Welch, and Martin Luther King to Rudolph Giuliani, there are as many leadership styles as there are leaders. In a study by Akdol and Arikboga, various leadership dimensions i.e. empowerment, accountability, standing back, humility, authenticity, courage and forgiveness were identified which influence the job satisfaction and performance of an organization [2]. Fortunately, business people and psychologists have developed useful, shorthand ways of describing the main leadership styles. The following literature review can help aspiring leaders to understand and adapt their own styles, so that they can improve their own leadership.

Autocratic leadership is an extreme form of transactional leadership, where a leader exerts high levels of power over his or her employees or team members. A common belief of many authoritarian leaders is that followers require direct supervision at all times or else they would not operate effectively [10]. Autocratic leaders make decisions independently with little or no input from the rest of the group. For some routine and unskilled jobs, however, this style can remain effective.

The bureaucratic leadership style was first described by 
Max Weber in 1947. Bureaucratic leaders work "by the book", ensuring that their staff follow procedures exactly. This is a very appropriate style for work involving serious safety risks (such as working with machinery, with toxic substances or at heights) or where large sums of money are involved (such as cash-handling).

Charismatic leadership style can appear similar to a transformational leadership style, in that the leader injects huge doses of enthusiasm into his or her team, and is very energetic in driving others forward. Charismatic leadership almost always endangers the boundaries set by traditional (coercive) or rational (legal) authority. It tends to challenge this authority, and is thus often seen as revolutionary [14].

The democratic or participative leadership style consists of the leader sharing the decision-making abilities with group members by promoting the interests of the group members and by practicing social equality [8]. This style demands the leader to make decisions on who should be called upon within the group and who is given the right to participate in, make and vote on decisions [19].

The laissez-faire leadership style is where all the rights and power to make decisions is fully given to the worker [13]. The French phrase "laissez-faire" means "leave it be" and is used to describe a leader who leaves his or her colleagues to get on with their work. It can be effective if the leader monitors what is being achieved and communicates this back to his or her team regularly.

Task-oriented leaders focus on getting the necessary task, or series of tasks, at hand in order to achieve a goal. These leaders are typically less concerned with the idea of catering to employees, and more concerned with finding the step-bystep solution required meeting specific goals. They will often actively define the work and the roles required, put structures in place, and plan, organize, and monitor progress within the team [9].

Relationship-oriented leadership is a contrasting style in which the leader is more focused on the relationships amongst the group and is generally more concerned with the overall well-being and satisfaction of group members [9]. On the other hand, developmental style, the most desirable style of leadership referred by Rao and Raju is aligned with the creation of empowerment, high morale, growth, learning and satisfaction of employees [18].

Bass developed the idea of two different types of leadership, transactional that involves exchange of labor for rewards and transformational which is based on concern for employees, intellectual stimulation, and providing a group vision [4], [3]. Burns stated that the transactional leader is given power to perform certain tasks and reward or punish for the team's performance [7]. Power is given to the leader to evaluate, correct, and train subordinates when productivity is not up to the desired level, and reward effectiveness when expected outcome is reached.

Bass extended the work of Burns by explaining the psychological mechanisms that underlie transforming and transactional leadership. $\mathrm{He}$ introduced the term "transformational" instead of "transforming". In many organizations, the transactional leaders (or managers) ensure that routine work is done reliably, while the transformational leaders look after initiatives that add value [5], [7]. Mehta also predicted those two leadership styles i.e. transformational and transactional leadership styles, which are significantly pursued in banking sector [17].

A good leader will find him or herself switching instinctively between styles according to the people and work they are dealing with. This is often referred to as "situational leadership". Effective leadership varies, not only with the person or group that is being influenced, but it also depends on the task, job or function that needs to be accomplished [11]. According to a study performed by Kroeck et al., charisma (or Idealized Influence) was found to be a variable that was most strongly related to leader effectiveness among Multifactor Leadership Questionnaire (MLQ) scales, a survey which identifies different leadership characteristics based on examples [15].

In light of the above literature, this paper intends to know about the variation of leadership styles in context to the banking industry of Bangladesh. The banking industry of Bangladesh at present is in the growth stage. However, the industry has been facing several problems in terms of low profitability (return on asset, return on equity and non-performing loan) after 2010. An effective leadership may provide the necessary power for improvement in supervision and regulatory capacity, and streamlining of enforcement of prudential guidelines. That is why leadership practices are relevant to discuss.

This study is basically undertaken with a view to understand the leadership styles pursued in the banking industry. The objectives can be further fragmented as to find out what style of leadership people normally prefer and practice most. Similarly, to identify what style of leadership people least use. Moreover, to examine whether people have clear perception of the leadership styles they pursue. Finally, to examine whether people switch among styles according to the situation they are dealing with.

\section{Objective of the Study}

a) To explore whether people have clear perception of the leadership styles they follow.

b) To find out which style of leadership people mostly follow, prefer and practice in the banking industry.

c) To examine whether people switch among leadership styles with the changing situations.

\section{Methodology}

In this descriptive type of study, a literature review is prepared and a survey is conducted to find out peoples' belief and choice towards leadership styles. Two set of structured questionnaires for leaders and subordinates based on interval scale is designed to conduct leadership style survey to collect data from industry professionals of top, mid and operational levels. The following Table 1 illustrates the sampling distribution. 
Table 1. Institution wise description of the sample.

\begin{tabular}{lll}
\hline SL No. & Name of financial institutions & No. of sample \\
\hline 1 & Dhaka bank ltd. & 7 \\
2 & Southeast bank ltd. & 9 \\
3 & Al-Arafah Islami bank ltd. & 4 \\
4 & EXIM bank ltd. & 4 \\
5 & Eastern bank ltd. & 3 \\
6 & Bank Asia ltd. & 5 \\
7 & BRAC bank ltd. & 8 \\
8 & Lanka Bangla securities ltd. & 8 \\
9 & Prime bank ltd. & 4 \\
10 & Janata bank ltd. & 4 \\
& Total & 56 \\
\hline
\end{tabular}

Secondary data have been collected from websites, books and periodicals, data bases, journal articles and archival records. This study is conclusive in nature and generally there is priority for quantitative analysis. Sampling method has been chosen as the judgment sampling. The findings should reflect the thought of the population on an aggregate basis. Top, mid and operational level officials including leaders and subordinates of different financial institutions in the country and the banking industry as a whole is the target population. Total 56 officials are surveyed which includes 20 leaders and 36 subordinates from 10 private, public and nonbank financial institutions. Face-to-face individual interviews were conducted in case of collecting the primary data.

In selecting leader (manager) respondents, we chose the corporate level managers who are top level decision makers and have proven track record up the organizational hierarchy. And in selecting subordinate respondents we chose the subsequent mid and functional level staff from the same financial institution.

\section{Analysis}

In this study, two sets of questionnaires (addressing leaders and subordinates) used in the survey contain statements on leadership styles. Next to each statement, there are numbers that represent how strongly one feels about the statement by using the following scoring system: Almost Always True - 5; Frequently True -4 ; Occasionally True -3 ; Seldom True -2 ; Almost Never True -1 .

The statements in the questionnaires related to each leadership styles are arranged in the following sequence: 1 . Autocratic style, 2. Participative style, 3. Laissez-faire style, 4. Bureaucratic style, 5. Transformational style, 6. Transactional style. This sequence subsequently continues to the end of the two questionnaires. It must be mentioned that each of the 30 statements in each of the two questionnaires are completely same. However, the statements are modified for the subordinates without changing the meaning. In addition, the sequence of the statements in the two questionnaires is same to each other.

So, adherence between leaders' and subordinates' responses can be easily identifiable that whether subordinates' evaluation regarding their leaders' pursued leadership style is matching with leaders' own assessment of his/her leadership style. Eventually, type of leadership practice in an organization can also be identified.

Two sample questionnaires for both leaders and subordinates are attached in the appendix section. These questionnaires are to help one assess what leadership style one normally operate out of. The lowest score possible for any style is 5 (Almost never) while the highest score possible for any style is 25 (Almost always).

The highest total point of the six styles indicates what style of leadership one normally follows. If one's highest score is 20 or more, it is a strong indicator of his/her normal style. The lowest of the six leadership style scores is an indicator of the style one least use. If ones' lowest score is 10 or less, it is a strong indicator that one normally does not operate out of this mode.

If two of the highest scores are same or close to same, one might be going through a transition phase, either personally or at work, except if one scores high in both the participative and the laissez-faire, in this case he/she is probably a laissez faire leader.

If there is only a small difference among the scores or all the scores close to same, then this indicates that one has no clear perception of the mode he/she operate out of, or he/she is a new leader and is trying to feel out the correct style for him/herself. It may also be possible that he/she is a situational leader pursues different styles in different situations. For better understanding of the analysis two filled respondents' questionnaires, one for leader (manager) and one for subordinate from Dhaka bank, are given in Table 2 and Table 3 respectively. Each and every questionnaire is analyzed in the same way.

It should be mentioned, the columns indicating by Q. represents the respective leadership style question numbers extracted from the main questionnaires, which are attached in the appendix section.

Table 2. Respondent 1: Leader, Dhaka Bank.

\begin{tabular}{llllll}
\hline Q. & Autocratic Style (score) & Q. & Participative Style (score) & Q. & Laissez-faire Style (score) \\
\hline 1 & 3 & 2 & 4 & 3 & 3 \\
7 & 2 & 8 & 5 & 9 & 4 \\
13 & 3 & 14 & 5 & 15 & 4 \\
19 & 4 & 20 & 5 & 21 & 3 \\
25 & 5 & 26 & 5 & 27 & 3 \\
Total & 17 & & 24 & & 17 \\
\hline
\end{tabular}


Table 2. Continued.

\begin{tabular}{lclclc}
\hline Q. & Bureaucratic Style (score) & Q. & Transformational Style (score) & Q. & Transactional Style (score) \\
\hline 4 & 4 & 5 & 5 & 6 & 3 \\
10 & 5 & 11 & 4 & 12 & 4 \\
16 & 5 & 17 & 4 & 18 & 4 \\
22 & 5 & 23 & 4 & 24 & 4 \\
28 & 3 & 29 & 5 & 30 & 4 \\
& 22 & & 22 & & 19 \\
\hline
\end{tabular}

The highest of the six scores here is 24 in the participative style. Apparently, the leader normally uses the participative style of leadership. The lowest of the six scores is 17 in the autocratic and laissez-faire style, which indicates the leader is a least user of these two styles.

Table 3. Respondent 2: Subordinate, Dhaka Bank.

\begin{tabular}{llllll}
\hline Q. & Autocratic Style (score) & Q. & Participative Style (score) & Q. & Laissez-faire Style (score) \\
\hline 1 & 5 & 2 & 3 & 3 & 1 \\
7 & 4 & 8 & 5 & 4 & 15 \\
13 & 5 & 14 & 4 & 4 & 21 \\
19 & 4 & 20 & 4 & 5 & 5 \\
25 & 5 & 26 & 5 & 27 & 19 \\
Total & 23 & & 21 & \\
\hline
\end{tabular}

Table 3. Continued.

\begin{tabular}{llllll}
\hline Q. & Bureaucratic Style (score) & Q. & Transformational Style (score) & Q. & Transactional Style (score) \\
\hline 4 & 5 & 5 & 5 & 5 & 6 \\
10 & 5 & 11 & 5 & 5 \\
16 & 5 & 17 & 4 & 12 & 18 \\
22 & 5 & 23 & 5 & 24 & 3 \\
28 & 5 & 29 & 5 & 4 & 2 \\
& 25 & & 24 & & 20 \\
\hline
\end{tabular}

The perceived leader is a practitioner of bureaucratic style according to the subordinate. The lowest of the six scores is 19 in the laissez-faire style that indicates the respondent subordinate assumes the leader as the least follower of laissez faire style.

\section{Results}

\subsection{Most Preferred Leadership Style}

According to the survey, 10 out of 20 leaders' most preferred style is bureaucratic style, depicted in Table 4. It is evident that $50 \%$ of the leaders normally pursue bureaucratic style. So, it is the most used style among leaders surveyed. Closer to bureaucratic style are participative and transformational styles. Followers of other styles are negligible in number. On the contrary, $77.78 \%$ subordinates advocate that their organizations' leaders (managers) pursue bureaucratic style. So, there is a consensus in leaders' and subordinates' responses on most preferred leadership style. According to theory $\mathrm{X}$, subordinates are reluctant to take responsibility, that's why managers have to be bureaucratic according to scientific management. Moreover, leadership styles influence the level of motivation and performance of an individual and man's motivation is influenced by changing ambitions. So it is noted that command and control leadership drains off ambition and they start to react as like as they feel [1], [12]. But the trend is changing towards transformational style in banking sector. According to the analysis this practice is also found in this study in Bangladesh perspective as the most two preferred style are bureaucratic and transformational [6].

Table 4. Most preferred leadership style: Comparison between leader-subordinate responses.

\begin{tabular}{lllll}
\hline \multirow{2}{*}{ Leadership style } & Leaders' response & \multicolumn{2}{l}{ Subordinates' response } \\
\cline { 2 - 5 } & Frequency & Percentage & Frequency & Percentage \\
\hline Autocratic style & 1 & $5 \%$ & 4 & $11.11 \%$ \\
Participative style & 8 & $40 \%$ & 3 & $8.33 \%$ \\
Laissez-faire & 3 & $15 \%$ & 1 & $2.78 \%$ \\
Bureaucratic style & 10 & $50 \%$ & 28 & $77.78 \%$ \\
Transformational style & 8 & $40 \%$ & 5 & $13.89 \%$ \\
Transactional style & 3 & $15 \%$ & 3 & $8.33 \%$ \\
\hline
\end{tabular}




\subsection{Least Preferred Leadership Style}

Leaders' least preferred style is laissez-faire style according to their self-assessment. $45 \%$ of the leaders voted that they least prefer laissez-faire style, illustrated in Table 5. The second next least pursued style is autocratic style of leadership. According to the subordinates, leaders least pursue laissez faire and participative style. Maximum $38.89 \%$ people voted for both the two styles. The second next least used style is autocratic style. So, there is a similarity in leaders' and subordinates' responses on least used leadership style.

Table 5. Least preferred leadership style: Comparison between leader-subordinate responses.

\begin{tabular}{lllll}
\hline \multirow{2}{*}{ Leadership style } & Leaders' response & & Subordinates' response \\
\cline { 2 - 5 } & Frequency & Percentage & Frequency & Percentage \\
\hline Autocratic style & 7 & $35 \%$ & 8 & $22.22 \%$ \\
Participative style & - & - & 14 & $38.89 \%$ \\
Laissez-faire & 9 & $45 \%$ & 14 & $38.89 \%$ \\
Bureaucratic style & - & - & 1 & $2.78 \%$ \\
Transformational style & 1 & $5 \%$ & 3 & $8.33 \%$ \\
Transactional style & 3 & $15 \%$ & 3 & $8.33 \%$ \\
\hline
\end{tabular}

\subsection{Leaders Going Through Transition}

There are leaders who are in transition between leadership styles. This transition is pointed out from the leaders' responses. It is basically determined on the basis of that if two of the highest scores are close to same or same, one might be going through transition. A maximum of $10 \%$ of the leaders are in transition in each bureaucratic to transformational style and participative to transformational style, showed in Table 6.

Leaders who are in transition, or seem to be in transition from the point of view of subordinates are also explored. According to subordinates' assessment, a maximum of $5.56 \%$ of the leaders are in transition in each bureaucratic to transformational style and autocratic to bureaucratic style.

It is noticeable that there is a consensus between leaders' and subordinates' responses on the point that leaders are in transition to a maximum extent between bureaucratic and transformational styles.

Table 6. Leaders in transition (comparison between leaders' and subordinates' responses).

\begin{tabular}{lll}
\hline Leadership styles & $\begin{array}{l}\text { Leaders' } \\
\text { responses }\end{array}$ & $\begin{array}{l}\text { Subordinates' } \\
\text { responses }\end{array}$ \\
\hline Bureaucratic - Transformational & $10 \%$ & $5.56 \%$ \\
Participative - Transformational & $10 \%$ & $2.78 \%$ \\
Autocratic - Bureaucratic & $5 \%$ & $5.56 \%$ \\
Bureaucratic - Transactional & $5 \%$ & $2.78 \%$ \\
Laissez-faire - Bureaucratic & $5 \%$ & - \\
Participative - Transactional & $5 \%$ & - \\
Laissez faire - Transactional & - & $2.78 \%$ \\
\hline
\end{tabular}

\subsection{Leaders and Subordinates Who May Not Have Clear Perception of the Leadership Styles}

$25 \%$ of the total surveyed leaders responded in such a way that there is only a small difference among the scores or all the scores of different styles are close to each other. This indicates, those leaders may not have clear perception of the leadership modes they pursue, or they are new leaders and are trying to feel out the correct style for themselves.

It may also be possible that those leaders are dealing and acting based on changing situations. Every situation does not match a particular style of leadership. So, the leaders may pursue different styles to deal with different situations that imply they are situational leaders.

On the contrary, $13.89 \%$ of the total surveyed subordinates responded in such a way that there is only a small difference among the scores or all the scores of different styles are very close to each other. Therefore, those subordinates may not have clear perception of the leadership styles of their respective leaders.

\section{Findings}

Firstly, the most practiced leadership style in the banking industry is bureaucratic style. It is evident from the leaders' responses that $50 \%$ of the leaders pursue bureaucratic style. Similarly, a maximum of $77.78 \%$ of the subordinates addressed that their leaders are mainly followers of bureaucratic style. So, subordinates' responses are matching with leaders' responses with regard to the most used leadership style. As both of the groups are agreeing on this point, it can be said that the two respondent groups gave honest and correct feedback to the two separate questionnaires.

Second, a significant number of the surveyed leaders $(48 \%)$ are in transition as they seem to pursue more than one style. And, majority (more than $50 \%$ ) of these $48 \%$ leaders are in transition between bureaucratic to transformational style and participative to transformational style. It may indicate that those bureaucratic and participative leaders may often swap with the transformational style.

Third, a maximum of $45 \%$ of the leaders responded that their least pursued leadership style is laissez-faire style. Correspondingly, a maximum of $38.89 \%$ of the subordinates' responses are aligning with the leaders' responses on this point that their leaders least practice laissez-faire style. 
However, same percentage of the subordinates (38.89\%) claim that their leaders least follow participative style.

Likewise, from subordinates' responses it is found, a maximum of $5.56 \%$ of the subordinates responded that there assessed leaders are in transition between bureaucratic to transformational styles. Here, we can see a match between leaders' and subordinates' responses regarding the transition of leadership styles.

Among the surveyed leaders, 25\% may not have clear perception of what leadership style they are pursuing, or they may be new in their roles and are trying to feel out the correct style for themselves. It may also be possible that those leaders are situational leaders acting in different ways in different situations and pursuing different styles simultaneously.

Finally, data reveal that $13.89 \%$ of the respondent subordinates may not have clear perception of the different leadership styles. This is because there is only a small difference among the weighted scores assigned by the subordinates or all the scores of different styles are very close. It could be possible also that the those leaders assessed by their subordinates are situational leaders and use different styles tailoring different situations and the subordinates perfectly marked the leaders and scored closely in different styles.

\section{Conclusion}

The above literature, discussion and analysis attempted to portray a picture of the leadership practices in the banking industry of Bangladesh. The particular style that a person needs in order to lead at a particular time in an organization depends on a variety of factors. Thus, the style that individuals use is based on a combination of their beliefs, values and preferences, as well as the organizational culture and norms encourage some styles and discourage others.

By the same token, majority of the top level managers in the banking industry found to pursue bureaucratic style, which is very much appropriate for works involving serious safety risks or where large sums of money are involved. Furthermore, laissez-faire style rationally found to be the least preferred style among senior managers of different financial institutions surveyed. Some corporate level managers found to be transformational in managing staffs and responsibilities that imply these managers are ideal leaders, who are value driven and care for their subordinates. Few of the senior level managers found to be switching in between styles and the underlying reason is yet to ascertain. Last but not least, there is an ample scope to further the study with a larger sample base.

\section{Limitations}

This study is based on only a single industry. So, it lacks generalization of findings for other industries. Moreover, the analysis is simple and no advanced statistical tool is used.

\section{References}

[1] Aishat, O. A., DaudSilong, A., Suandi, T., \& Oladipo. (2015). Leadership Styles of Managers and Employee's Job Performance in a Banking Sector. IOSR Journal Of Humanities And Social Science (IOSR-JHSS), 68-73.

[2] Akdol \& Arikboga (2015). The Effects of Leader Behavior on Job Satisfaction: A Research on Technology Fast 50 Turkey companies. World conference on technology, Innovation and Entrepreneurship. Procedia-Social and Behavioural Sciences 195, 278-282.

[3] Bass, B. M., \& Riggio, R. E. (2006). Transformational leadership (2nd ed.). Mahwah, NJ: Lawrence Erlbaum Associates Publishers; US.

[4] Bass, B. M.; Avolio, B. J.; Atwater, L. E. (1996). The transformational and transactional leadership of men and women. Applied Psychology: an International Review 45 (1): 5-34.

[5] Bass, B. M. (1985). Leadership and performance beyond expectations. New York: Free Press; Collier Macmillan.

[6] Belias, D., \& Koustelios, A. (2014). Transformational Leadership and Job Satisfaction in the Banking Sector: A Review. International Review of Management and Marketing, 187-200.

[7] Burns, J. M. (1978). Leadership. New York: Harper \& Row. LEADERSHIP QUARTERLY, 2 (1).

[8] Foster, D. E. (2002). A method of comparing follower satisfaction with the Authoritarian, Democratic, and Laissezfaire Styles of leadership. Communication Teacher 16 (2): 4-6.

[9] Ebert, R. J., \& Griffin, R. W. (2010). Business essentials (8th ed.). Upper Saddle River, NJ: Prentice Hall. pp. 135-136. ISBN 0-13-705349-5.

[10] Hackman, M. Z., \& Johnson, C. E. (2009). Leadership: A communication Perspective (5th ed.). Long Grove, IL, Waveland Press.

[11] Insert Hersey, P., and Blanchard, K. H. (1977). Management of Organizational Behavior 3rd Edition-Utilizing Human Resources. New Jersey/Prentice Hall.

[12] Jain, A., \& Chaudhary, S. (2014). Leadership Styles of Bank Managers in Nationalized Commercial Banks of India. SMS Varanasi, 98-105.

[13] Johnson, C. E.; Hackman, M. Z. (2003). Leadership, a communication perspective (4 ed.). Waveland Press. p. 38 ISBN 9781577662846.

[14] Kunin, S. D. (2003). Religion: the modern theories, University of Edinburgh, p. 40. ISBN 0-7486-1522-9.

[15] Kroeck, K. G., Lowe, K. B., \& Sivasubramaniam, N. (1996). Effectiveness correlates of transformational and transactional leadership: A meta-analytic review of the MLQ literature. The Leadership Quarterly, 7 (3), 385-425.]

[16] Karavelioğlu, A. M. (2014). Analysis of Leadership Styles in Banking Sector in North Cyprus: Testing Factors Effecting Authoritarian Style and a Model for Banking Sector in a Small Island Economy. International Journal of Regional Development, 39-64. 
[17] Mehta, D. S., \& Kaur, R. (2016). A Review Paper on leadership styles of managers among public and private sector banks and its relationship with other constructs. International Journal of New Innovations in Engineering and Technology, 107-115.

[18] Rao, T. V. and Rao, Raju (2012) "A study of leadership styles and their impact" Academy of HRD, International research conference on HRD IN Asia, 2012, IIM Banglore.
[19] Woods, P. A. (2010). Democratic leadership: drawing distinctions with distributed leadership. International Journal of Leadership in Education 7 (1): 3-36. 